\title{
Current Seasonal Variations in Physicochemical and Heavy Metals Parameters of Sewage Treatment Plant Effluent and Suitability for Irrigation
}

\author{
Chandan Maurya ${ }^{\circledR}$, Janendra Nath Srivastava \\ Department of Botany, Dayalbagh Educational Institute, Agra, India \\ Email: chandankmaurya@gmail.com
}

How to cite this paper: Maurya, C. and Srivastava, J.N. (2019) Current Seasonal Variations in Physicochemical and Heavy Metals Parameters of Sewage Treatment Plant Effluent and Suitability for Irrigation. Journal of Water Resource and Protection, 11, 852-865.

https://doi.org/10.4236/jwarp.2019.117052

Received: June 21, 2019

Accepted: July 27, 2019

Published: July 30, 2019

Copyright $\odot 2019$ by author(s) and Scientific Research Publishing Inc. This work is licensed under the Creative Commons Attribution International License (CC BY 4.0). http://creativecommons.org/licenses/by/4.0/

\section{Open Access}

\begin{abstract}
The study aims to investigate the current extent of physicochemical parameters and heavy metal contamination in the effluent of the Jaganpur sewage treatment plant (STP), Dayalbagh, Agra India. Majority of the nearby farmers have access to use of STP effluent in irrigation purposes for growing major edible crops. The problems of using STP effluent for irrigation purpose, continuous water quality analysis required. To check the quality of irrigation water, substantial physicochemical parameters accordance to Indian Standards (IS-Reaffirmed 2002/2003) analysed to calculate Sodium absorption ratio (SAR) and Residual sodium carbonate (RSC). To estimate the heavy metal pollution index (HPI) and metal quality index (MQI), toxic Heavy metals such as As, Cr, Mn, Fe, Ni, Cu, Zn, Pd, Cd, Co, and B also determined in the STP effluent with an AAS and results verified with ICP-OES against certified standards. The high value of SAR (range 13 to 20 ) and RSC (range -10 to 11) in STP effluent exceeded the permissible limit for irrigation purpose. On the other hand, HPI and MQI values (1692.4 and 58.1, respectively) show that high metal contamination mainly due to industrial and domestic wastewater does not treat appropriately in the sewage treatment plant. Thus it is suggested that further studies are carried out on the STP effluents to improve the water quality through proper treatment. Treated wastewater used for irrigation purposes needs to analyse the contamination like heavy metals and pinpoint the pollution sources.
\end{abstract}

\section{Keywords}

Heavy Metals, Physico-Chemical Parameters, Sewage Treatment Plants Effluent, Irrigation Water 


\section{Introduction}

This Wastewater treatment is a global concern, critically interlinks to sustainable agriculture, animal and human health and environmental quality worldwide, including Indian subcontinent [1]. The Yamuna and many other rivers are getting polluted and contaminated on receiving the considerable quantity of untreated wastewater drained from urban and industrial sources [2]. Total wastewater generation from urban areas in India is above 39,000 MLD, out of which only $34 \%$ is treated [3]. Major Indian cities also extract effluent from sewage treatment plants (STP) for agriculture and industrial usage, therefore, quality of STP effluents stands critical from human, animal and crops health as well as an ecological point of view. In Agra, Jagnpur STP has a catchment area of over $30,045.87 \mathrm{~m}^{2}$ and perimeter of about $756.07 \mathrm{~m}$. STP effluent directly dumps into Yamuna River which traverses seven states (Uttarakhand, Himachal Pradesh, Haryana, Delhi, Rajasthan, Uttar Pradesh and Madhya Pradesh) but its water polluted in Delhi and Uttar Pradesh segments [2]. To abate the contamination and pollution of Yamuna, Government of India launched a mega project called Yamuna Action Plan in 1993, however, restoration of the ecological fitness of Yamuna water to the required water quality standards is yet a big concern. Farmer's especially poor and marginal one, lift STP effluent during the summer season due to the scarcity of river water. The efficiency of STP and the quality standards of its effluent show a significant impact on the quality of Yamuna water and irrigate crops which can be detrimental to crop quality, soil, human and animal health and environmental quality [3].

On the other hand, contamination of the Yamuna River by toxic heavy metals is a serious environmental problem and needs to be monitored regularly as heavy metals are toxic due to their non-degradable nature and bio-accumulation through the food chain. In many parts of the world, STP effluent or untreated wastewater is being used for irrigation in agriculture crops field without assessing its suitability leading to deterioration in the quality of soil as well as a crop [4] [5]. Toxic Heavy metal pollution index (HPI) helps identify and quantify trends in water quality concerning spatial variation in the concentration of heavy metals. The metal quality index (MQI) is computed to assess the suitability of water resources for drinking/irrigation purpose concerning metals [6]. Pearson's correlation analysis is a useful tool for the identification of pollution sources [7] [8].

In this backdrop, a study covering about whole Dayalbagh stretch conducted during 2014 at six sites in Agra districts of Uttar Pradesh state which dominantly beset with sandy loam soils, semi-arid climate and an annual rainfall of about $550-750 \mathrm{~mm}$. The already concluded studies on STP effluent quality indicate that fitness of water for irrigation of crops near Dayalbagh, Agra is highly variable and unpredictable concerning a location within city limits and time [9] [10]. Therefore, this study which involves a Sewage treatment plant and less studied stretch of $293.4 \mathrm{~m}$ was carried out to assess the suitability of STP effluent for ir- 
rigation to crops during winter, summer, rainy and post-rainy seasons. This paper discusses the physicochemical properties, and heavy metal toxicity of STP effluent vis-à-vis designate irrigation water quality guidelines to indicate its fitness for crops for an advisory to the farmers.

\section{Methodology}

\subsection{Sampling Site}

Sampling sites selected along $470.54 \mathrm{~m}$ stretches of Jaganpur STP (14 MLD) site in Agra districts of Uttar Pradesh (Figure 1(a)). Another site is connected with Jaganpur STP effluent for the irrigation uses of nearby farmers (Figure 1(b)). Sample collected from STP influent, mid and effluent, in a composite manner and sampled during each season, i.e., winter (Mid-November to Mid-March), summer (Mid-March to Mid-July), rainy (Mid-July to Mid-September) and post-rainy (Mid-September to Mid-November).In this paper results only focused on effluent samples because of very insignificant differences between other sampling sites.

\subsection{Analysis of Physicochemical Parameters}

Physicochemical parameters viz., $\mathrm{pH}$, electrical conductivity (EC), ions concentration (boron, $\mathrm{Na}^{+}, \mathrm{Ca}^{2+}, \mathrm{Mg}^{2+}, \mathrm{HCO}^{3-} \mathrm{CO}_{3}^{2-}, \mathrm{Cl}^{-}$and $\mathrm{NO}_{3}^{2-}$ ) were estimated in STP effluent, collected in pre-sterilised HDPE plastic bottles of $100 \mathrm{ml}$, following standard methods and procedures where calcium and magnesium (total hardness) determined by versenate (EDTA) Method, sodium ion determination carried out directly with the help of flame photometer and standard curves prepared by taking known concentration of $\mathrm{Na}^{+}$. The determination of Carbonates and bicarbonates (total alkalinity) and Chloride by simple acidimetric titration nitrate in water determined by phenol disulphonic acid method [11] [12]. At every sampling site, three samples collected, i.e., from influent, mid and effluent of the STP and one each at either side of STP effluent storage pond supplied to Dayalbagh community from about one-foot depth. These samples were composited and subjected to physicochemical and heavy metal analysis. The physicochemical parameters so determined compared with the standard irrigation water quality guidelines [11] [12], which has presented in (Table 1). Sodium toxicity hazard assessed through determining SAR and RSC [11] [12] using following standard Equations ( $1 \& 2)$ respectively.

$$
\begin{gathered}
S A R=\left[\mathrm{Na}^{+}\right] / \operatorname{SQRT}\left\{\left(\left[\mathrm{Ca}^{2+}\right]+\left[\mathrm{Mg}^{2+}\right]\right) / 2\right\} \\
R S C=\left(\mathrm{HCO}_{3}^{-}+\mathrm{CO}_{3}^{2-}\right)-\left(\mathrm{Ca}^{2+}+\mathrm{Mg}^{2+}\right)
\end{gathered}
$$

\subsection{Analysis of Heavy Metals}

STP effluent samples collected from the Jaganpur "sewage treatment plant" at all three sites during all season. The samples collected in a manner of three composites taken from 1 foot below the water surface using pre-sterilized $500 \mathrm{ml}$ 

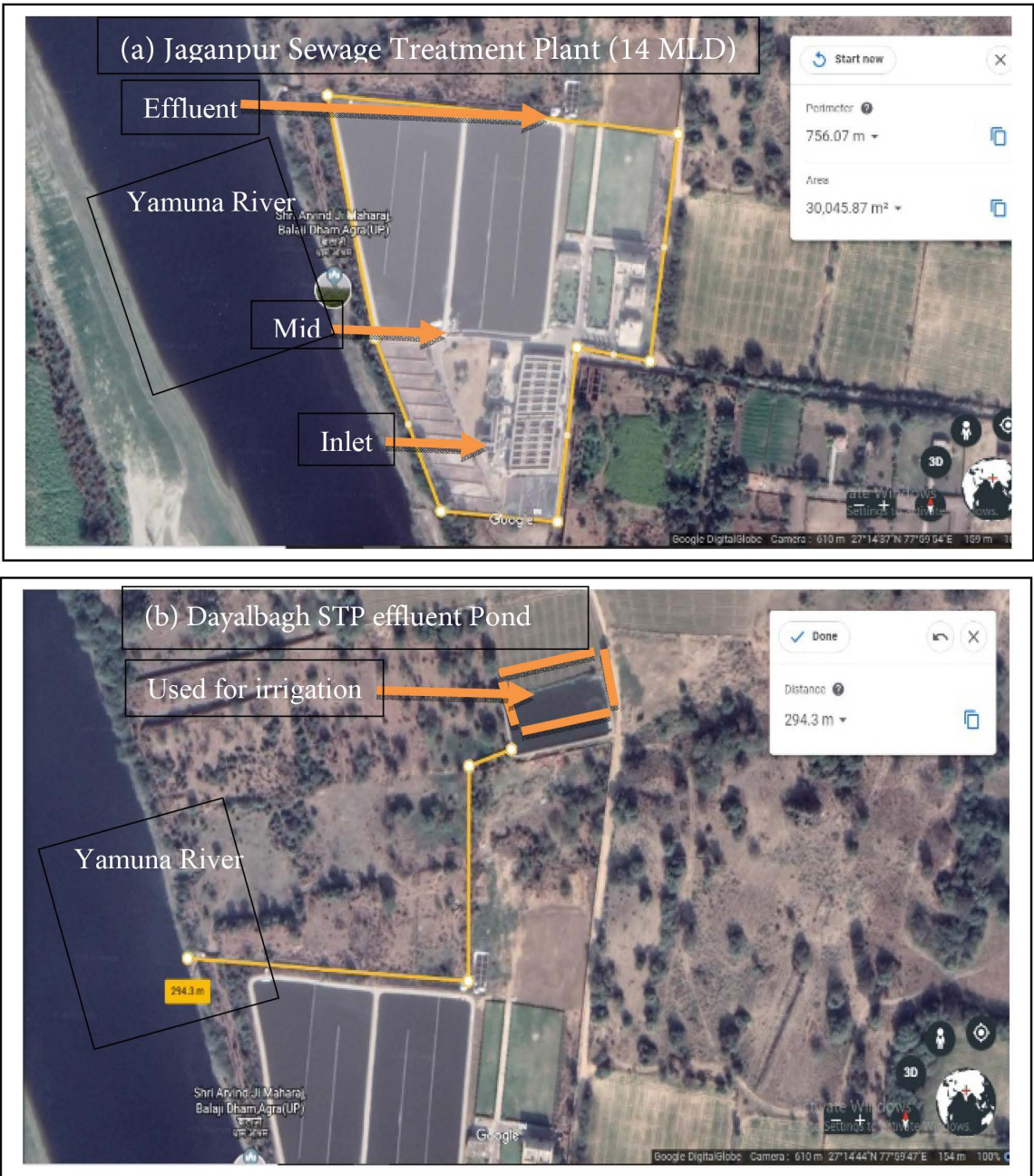

Figure 1. Google Earth picture of the study site (a) Jaganpur STP; (b) Dayalbagh STP effluent Pond Agra (U.P) India.

Table 1. Standard irrigation water quality guidelines Ayers and Westcot (1994).

\begin{tabular}{ccccc}
\hline Parameter & Permissible & Moderately safe & Moderately unsafe & Unsafe \\
\hline $\mathrm{pH}$ & $6.5-8.0$ & - & - & $>8$ \\
$\mathrm{EC}(\mathrm{ds} / \mathrm{m})$ & $<0.7$ & $0.7-3.0$ & - & $>3.0$ \\
$\mathrm{RSC}(\mathrm{meq} / \mathrm{L})$ & $<1$ & - & $1.25-2.5$ & $>2.5$ \\
$\mathrm{SAR}$ & $<3$ & $3-9$ & - & $>9$ \\
Boron $(\mathrm{mg} / \mathrm{L})$ & $<2.0$ & $2.0-2.5$ & $2.5-3.0$ & $>3.0$ \\
Chloride $(\mathrm{meq} / \mathrm{L})$ & $<4$ & $4-10$ & - & $>10$ \\
BOD $(\mathrm{mg} / \mathrm{L})$ & $\leq 100$ & - & - & $>100$ \\
Bicarbonate $(\mathrm{meq} / \mathrm{L})$ & $<1.5$ & $1.5-8.5$ & - & $>8.5$ \\
\hline
\end{tabular}

bottles to avoid unpredictable changes in characteristics generally HDPE bottles used. STP effluent samples collected were placed at $4^{\circ} \mathrm{C}$ in an ice-jacket and transported to the laboratory immediately for further analysis. The collected 
samples acidified with concentrated nitric acid to a $\mathrm{pH}$ below 2.0 to minimise adsorption and precipitation on bottles walls as required by the standard procedure. The concentrations of heavy metals determined using an atomic absorption spectrometry (Perkin-Elmer, 3300/96, MHS-10) after the acid-digestion procedure for heavy metals analysis. All analyses carried out in triplicate, and the results expressed as the mean. The overall quality of river water concerning the content of heavy metals assessed by HPI values and its critical value is 100 . The weighted arithmetic average of the concentrations used to calculate HPI [13] values using the Equation (3).

$$
H P I=\frac{\sum_{i=1}^{n} W i Q i}{\sum_{i=1}^{n} W i}
$$

where $W i=$ the unit weightage defined as the reciprocal value of $S i$.

$S i=$ the maximum permissible limit for irrigation water [14], and $n$ is the number of parameters considered.

$Q i=$ the sub-index of the i-th parameter and calculated by Equation (4)

$$
Q i=\sum_{i=1}^{n} \frac{M i}{S i} \times 100
$$

where $M i=$ the monitored value of the heavy metal,

$S i=$ the standard value of the $\mathrm{i}$-th parameter, in $\mathrm{ppm}(\mu \mathrm{g} / \mathrm{L})$.

(The higher the concentration of heavy metals compared to its respective maximum permissible limit $(S i)$, the quality of the water will be worse.)

$M Q I$ value below one is a threshold of warning [10] [14], the $M Q I$ is calculated by Equation (5)

$$
M Q I=\sum_{i=1}^{n} \frac{M i}{S i}
$$

The data were statistically analysed using the SPSS 20.0 statistical software package to calculate Pearson's correlation coefficient and level of significance $(\mathrm{p}<0.01$ and $\mathrm{p}<0.05)$.

\section{Results and Discussion}

\section{1. pH and Electrical Conductivity (Soluble Salts Concentration)}

The $\mathrm{pH}$ of STP effluent found alkaline and register conspicuous variations at different sites and seasons (range: 7.6 to 9.6), however, it was most alkaline in rainy season (8.5 to 9.6), slightly alkaline in summer season (8.5 to 9.3) and moderate in post-rainy season (7.9 to 8.4 ) and winters (7.6 to 8.2). The irrigation quality guidelines suggest that at this $\mathrm{pH}$ range, degree of restriction on the use of water for irrigation can moderate to severe for all the crops and soil types. Earlier studies of [14] also well corroborate with these findings on STP effluent $\mathrm{pH}$. EC at different sites followed the order: rainy $(2.30$ to $2.58 \mathrm{dS} / \mathrm{m})>$ post rainy season $(2.0$ to $2.50 \mathrm{dS} / \mathrm{m})>$ summer $(2.0$ to $2.5 \mathrm{dS} / \mathrm{m})>$ winter season $(1.8$ to $2.1 \mathrm{dS} / \mathrm{m}$ ). Higher EC during rainy may be a cumulative effect of more solubility of ions, higher domestic wastewater discharge on account of more con- 
sumption of water, the higher flow rate from surface of water bodies and lower flow rate of the STP effluent. The lowest EC of STP effluent during the winter season can ascribe to low overflow runoff from STP and resultant proper treatment of dissolved ions that directly determine EC (Figure 2).

It concluded that EC of STP effluent at various sampling sites during different seasons was found to lie in slight to moderate range of restrictive use as per the irrigation water quality guidelines. These findings on the EC of STP water are supported by [6] [15]. As such, care needs to apply on STP effluent in excessive quantity regularly in crops since it may involve of accumulation of salts in the crop root zone and build of adverse osmotic potential. Nevertheless, on sandy loam soils of area STP water can be used at moderate to optimum application levels with or without dilution. Infiltration rate of salts affects crops roots [16] [17].

\subsection{Total Alkalinity and Chloride}

Alkalinity becomes a concern at high $\mathrm{pH}$ (7.6 to 9.6), high ion concentration ( $>10$ meq/L) and under drip or sprinkler methods of irrigation given the deposition of lime on roots that causes iron-induced chlorosis [18] [19]. Data depict that bicarbonate concentration in STP effluent, i.e., Post rainy season (36 to 81 $\mathrm{meq} / \mathrm{L})>$ rainy season $(34$ to $72 \mathrm{meq} / \mathrm{L})>\operatorname{summer}(41$ to $55 \mathrm{meq} / \mathrm{L})>$ winter season $(16.0$ to $73.0 \mathrm{meq} / \mathrm{L})$ was found to be in moderate to severe restrictive range of water use for crops (Figure 3 ).

Chloride concentration in STP effluent followed an order i.e., summer (17.2 to $28.3 \mathrm{meq} / \mathrm{L})>$ rainy season $(15.5$ to $26.1 \mathrm{meq} / \mathrm{L})>$ winter $(13.9$ to $24.1 \mathrm{meq} / \mathrm{L})>$ post-rainy season (13.3 to $21.2 \mathrm{meq} / \mathrm{L}$ ). These results on bicarbonate and chloride in STP water also corroborate with findings of [20] [21]. As such, chloride concentration in STP water was found moderate to severe restrictive use for irrigation of crops in the zones of Dayalbagh Site.

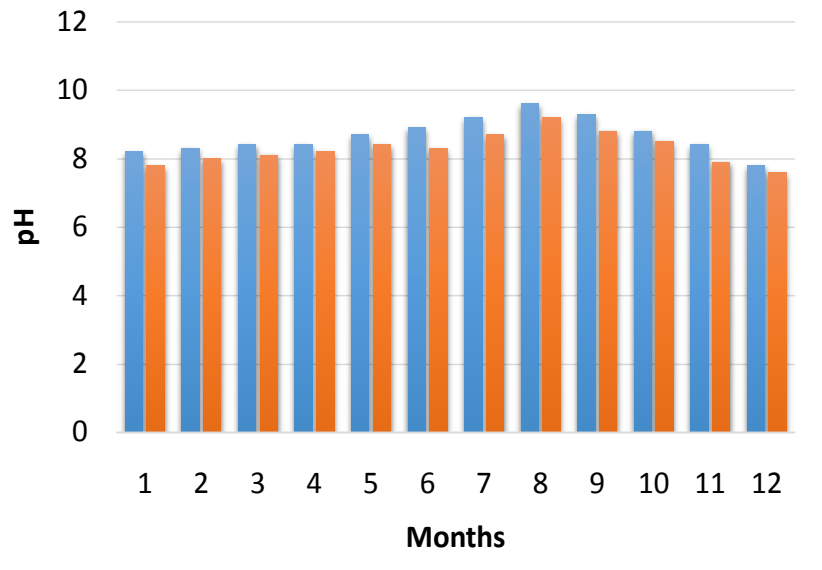

(a) $\mathrm{pH}$

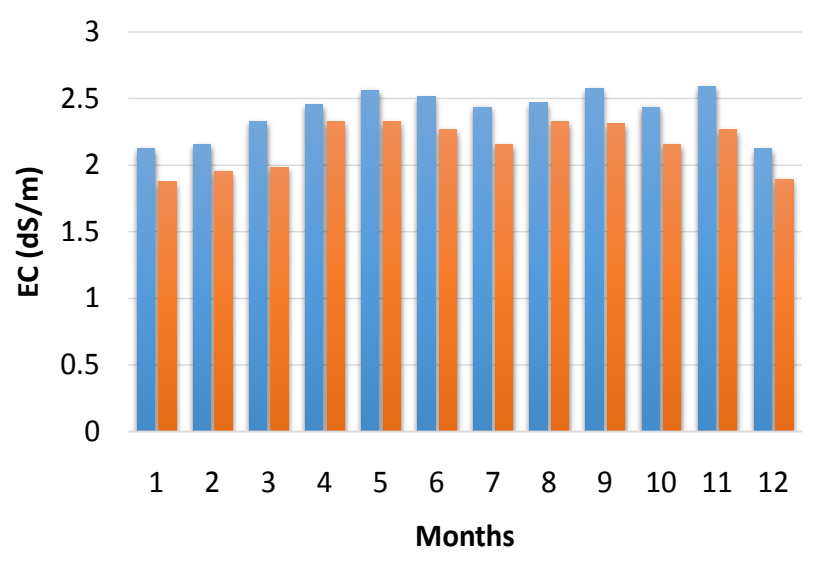

(b) Electrical Conductivity

Figure 2. Seasonal variations in (a) $\mathrm{pH}$ and (b) Electrical conductivity (EC dS/m) of STP effluent. 


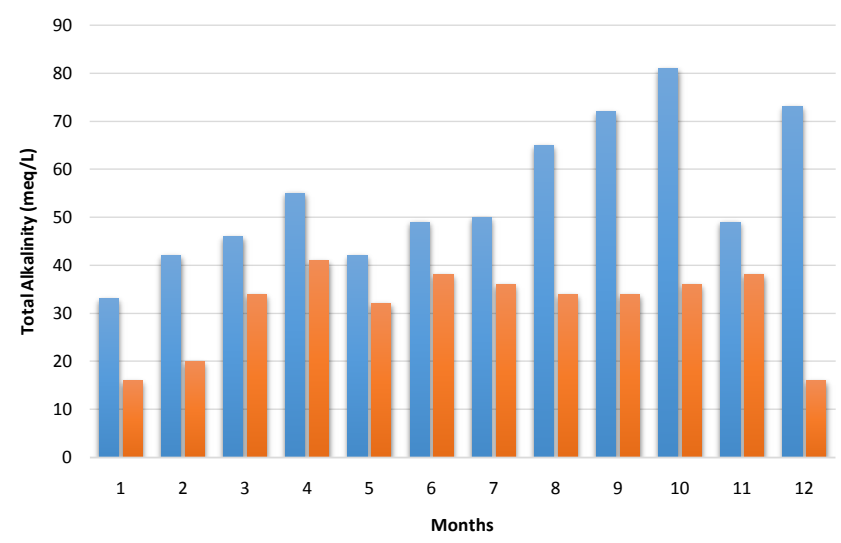

(a) Total Alkalinity

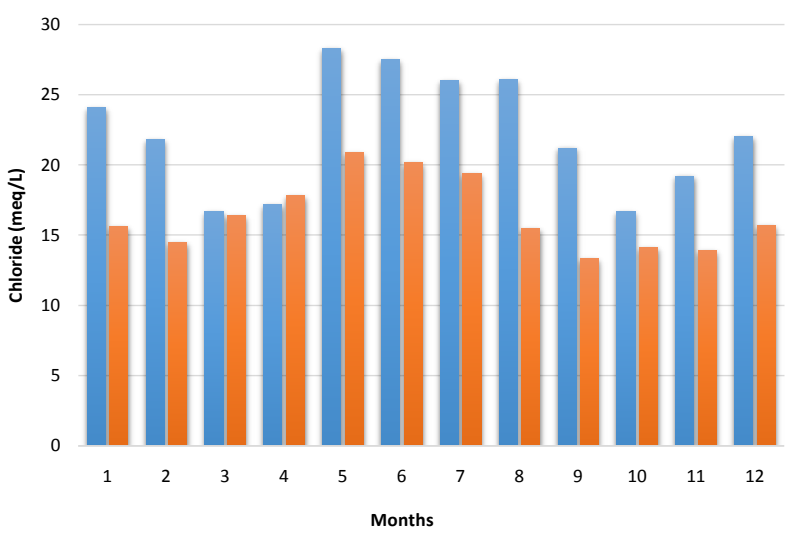

(b) Chloride

Figure 3. Seasonal variations in (a) Bicarbonate (meq/L) and (b) Chloride (meq/L) of STP effluent.

\subsection{Sodium Absorption Ratio and Residual Sodium Carbonate}

SAR, an indicator of mitigation of $\mathrm{Na}+$ hazard due to the presence of $\mathrm{Ca}^{2+}$ and $\mathrm{Mg}^{2+}$ ions, was found to vary seasonally in order of winter (11.9 to 20.3) > rainy season $(10.7$ to 16.8$)>$ summer $(10.2$ to 16.8$)>$ post-rainy season (10.1 to 16.7$)$. RSC was found to vary in order of summer $(-6$ to 11$)>$ rainy $(-4$ to 11$)>$ Post rainy ( -3 to 9 ) $>$ winter ( -6 to 8 ) (Figure 4 ). SAR values show that STP effluent is slight to moderate degree of restriction from sodium toxicity hazard point of view as per the standard irrigation water quality guidelines. However, the values of SAR for Jaganpur STP effluent are much higher than reported for other Sewage treatment plant by [11] [22] [23], which indicate inefficiency of treating domestic wastewater in STPs.

Both EC and SAR of irrigation water antagonistically affects water infiltration rate in soil. Therefore, EC and SAR of STP effluent at different sites correlated, and it found that from water infiltration hazard point of view STP water cannot be used without any further treatment at all sites in different seasons. Since sodium hazard increases with increase in the concentration of bicarbonate ions due to precipitation of $\mathrm{Ca}^{2+}$ and $\mathrm{Mg}^{2+}$ as carbonates, therefore, RSC becomes highly crucial in determining the quality of irrigation water. RSC of STP effluent at various sampling sites was positive in all seasons, which shows not suitable for use in agriculture. These results are also in conformity with the findings on the RSC of river water by [24] [25].

\subsection{Nitrate and Sodium}

Nitrate $\left(\mathrm{NO}_{3}^{2-}\right)$ concentrations showed seasonal variations in order of rainy season $(16.3$ to $30.1 \mathrm{mg} / \mathrm{L})>$ summer $(10.87$ to $27.4 \mathrm{mg} / \mathrm{L})>$ post-rainy season (10.8 to $18.7 \mathrm{mg} / \mathrm{L})>$ winter $(10.5$ to $15.2 \mathrm{mg} / \mathrm{L})$. Sodium ion concentrations showed seasonal variations in order of summer (67 to $99.2 \mathrm{meq} / \mathrm{L}$ ) $>$ winter (67 to $99 \mathrm{meq} / \mathrm{L})>$ rainy season $(68$ to $96.2 \mathrm{meq} / \mathrm{L})>$ post-rainy season $(67.2$ to 96 meq/L) (Figure 5). 


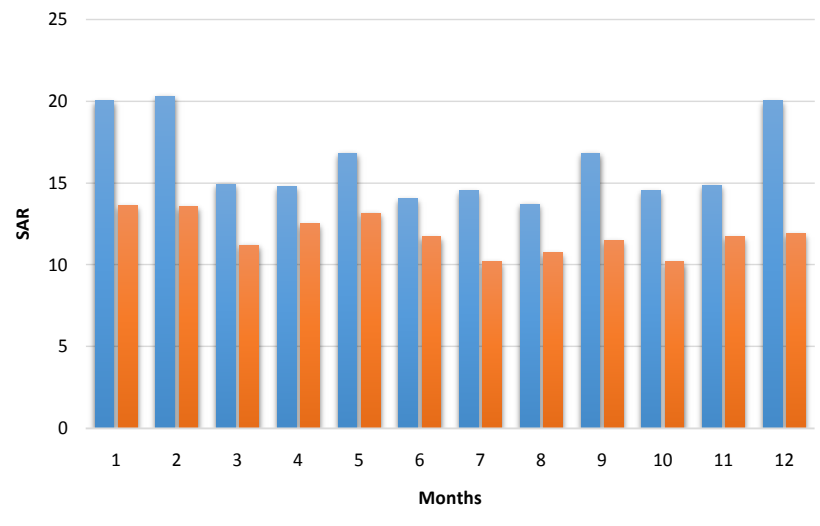

(a) Sodium Absorption Ratio

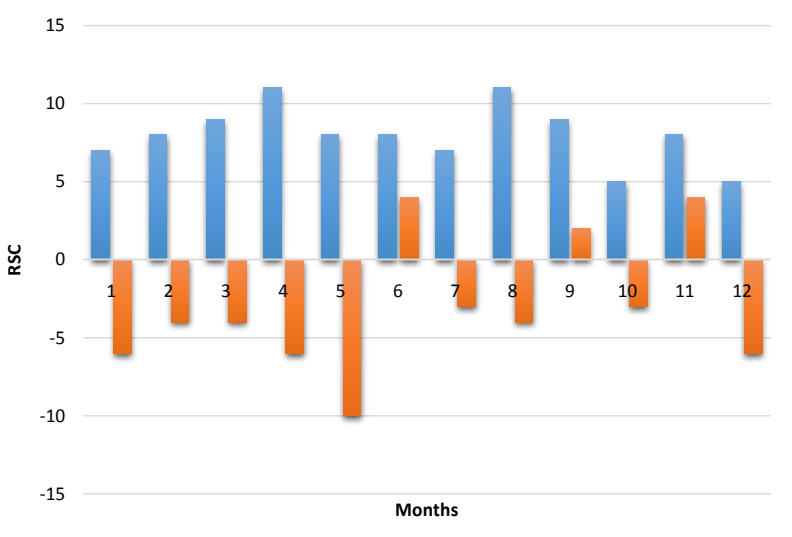

(b) Residual Sodium Carbonate

Figure 4. Seasonal variations in (a) SAR and (b) RSC of STP effluent.

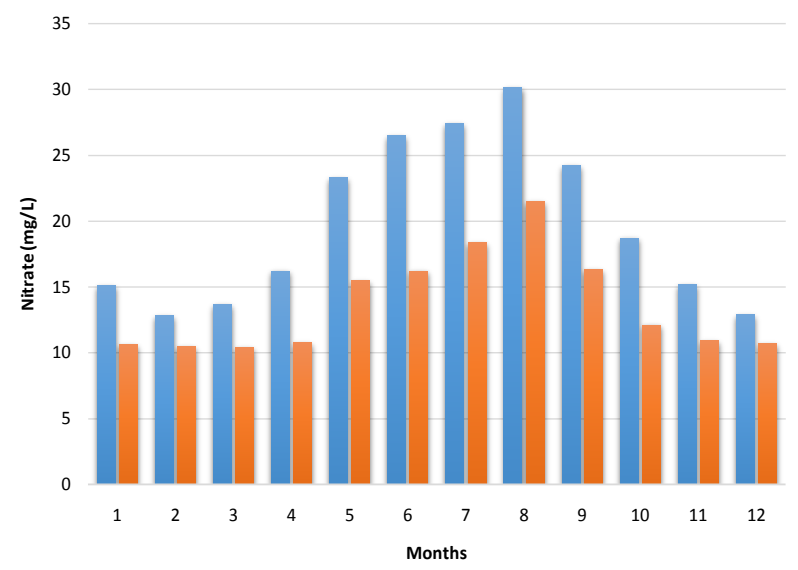

(a) Nitrate

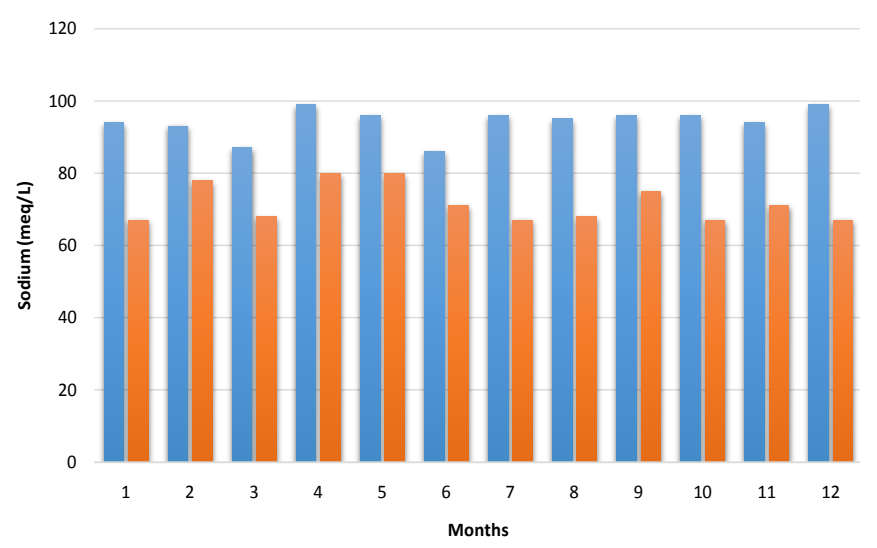

(b) Sodium

Figure 5. Seasonal variations in (a) Nitrate (mg/L) and (b) Sodium (meq/L) of STP effluent.

A higher concentration of nitrate and sodium in STP water during the rainy and post-rainy season over summer, links to high runoff input from agricultural fields. As per the standard irrigation water quality guidelines, with an actual nitrate-N level in STP water, it cannot be used without any prior efficient treatment. Similar results on nitrate concentrations reported by Sharma et al. (2017).

\subsection{Boron}

Boron, an essential element for crop plants becomes toxic above critical levels [26]. Boron in STP water contributed via chemical weathering and anthropogenic inputs [27]. The concentration of boron in STP water followed seasonal variations in order of rainy season $(1.5$ to $2.36 \mathrm{mg} / \mathrm{L})>$ post-rainy season $(1.1$ to $2.31 \mathrm{mg} / \mathrm{L})>\operatorname{summer}(1.3$ to $2.29 \mathrm{mg} / \mathrm{L})>$ winter $(0.5$ to $1.13 \mathrm{mg} / \mathrm{L})>$. Boron concentration STP waterfalls under the category of slight moderate restrictive use. Many authors worked on water quality of STPs in the Indian subcontinent conformity with results [28] [29]. 


\subsection{Heavy Metals}

The concentrations of nine heavy metals analysed for all seasons. The mean concentration of heavy metals in STP effluent followed the order $\mathrm{Pb}(1480$ $\mathrm{PPB})>\mathrm{Zn}(1159 \mathrm{PPB})>\mathrm{B}(1138 \mathrm{PPB})>\mathrm{Fe}(805 \mathrm{PPB})>\mathrm{Mn}(171 \mathrm{PPB})>\mathrm{Co}$ $(163 \mathrm{PPB})>\mathrm{As}(129 \mathrm{PPB})>\mathrm{Cr}(123 \mathrm{PPB})>\mathrm{Cd}(119 \mathrm{PPB})$ (Table 2). The concentration of all heavy metals was highest at Jagnpur STP which due to the inefficient treatment of wastewater coming from the fertiliser and chemical industries and residential areas of the city. Heavy metals viz., $\mathrm{Fe}, \mathrm{Pb}, \mathrm{Zn}$ and $\mathrm{B}$ found within permissible limits for irrigation water quality at all sites. Whereas other heavy metals were above permissible limits for irrigation water quality, its source was wastewater coming from painting and electroplating industries located in the city. As, Cd, Cr, Co and Mn were found higher than maximum permissible limit for irrigation water quality at influent and effluent sites of STP which accounted due to Chemical, Municipal and fertiliser industries. $\mathrm{Cu}$ and $\mathrm{Cd}$ were found higher than the maximum permissible limit for irrigation water quality at effluent.

The HPI values determined using mean concentrations of nine heavy metals ( $\mathrm{Fe}, \mathrm{Pb}, \mathrm{B}, \mathrm{Cd}, \mathrm{Zn}, \mathrm{Cr}, \mathrm{Cu}, \mathrm{Cd}$ and $\mathrm{Mn}$ ) (Table 3). The critical value of the HPI is 100 [13]. The mean HPI for STP effluent for all-season means was found very high, i.e., 1692.4 indicating high heavy metal pollution. The high HPI values were mainly due to industrial and domestic wastewater does not treat appropriately in the sewage treatment plant.

The metal quality index was used to estimate total metal pollution of STP effluent for irrigation. All sites along the studied stretch seriously threatened with metal pollution for irrigation (MQI > 1), MQI reached 58.19 at Dayalbagh site.

The Pearson correlation analysis for heavy metal content in STP effluent revealed that there were significant strong positive correlations $(p<0.05)$ between all the nine heavy metals (Table 4). A positive correlation between heavy metals analysed at different sites showed either an association/interaction between the

Table 2. Heavy metal concentrations in STP effluent at different seasons and its statistical values to determine the HPI and MQI values.

\begin{tabular}{ccccccc}
\hline Metals & Winter & Summer & Rainy & Post Rainy & Average & SD \\
\hline As & 129 & 154 & 161 & 169 & 153.25 & 17.29 \\
B & 1138 & 2298 & 2361 & 2318 & 2028.75 & 594.41 \\
$\mathrm{Cd}$ & 119 & 120 & 190 & 260 & 172.25 & 67.28 \\
$\mathrm{Cr}$ & 123 & 169 & 231 & 289 & 203.00 & 72.42 \\
$\mathrm{Co}$ & 163 & 184 & 197 & 283 & 206.75 & 52.73 \\
$\mathrm{~Pb}$ & 1480 & 1687 & 1775 & 1831 & 1693.25 & 154.03 \\
$\mathrm{Mn}$ & 171 & 201 & 279 & 366 & 254.25 & 87.31 \\
$\mathrm{Zn}$ & 1159 & 1195 & 1328 & 1494 & 1294.00 & 151.86 \\
$\mathrm{Fe}$ & 805 & 1389 & 1576 & 1751 & 1380.25 & 411.00 \\
\hline
\end{tabular}


Table 3. Heavy metal pollution index (HPI) calculations for STP effluent based on average heavy metal concentration.

\begin{tabular}{ccccccc}
\hline Metals & $\mathrm{Mi}$ & $\mathrm{Si}$ & $\mathrm{Wi}(1 / \mathrm{Si})$ & $\mathrm{Qi}\left(\mathrm{Mi} / \mathrm{Si}^{*} 100\right)$ & $\mathrm{Wi}^{*} \mathrm{Qi}$ & $\mathrm{MQI}$ \\
\hline $\mathrm{As}$ & 153.25 & 10 & 0.10 & 1532.50 & 153.25 & 15.33 \\
$\mathrm{~B}$ & 2028.75 & 5000 & 0.00 & 40.58 & 0.01 & 0.41 \\
$\mathrm{Cd}$ & 172.25 & 10 & 0.10 & 1722.50 & 172.25 & 17.23 \\
$\mathrm{Cr}$ & 203 & 100 & 0.01 & 203.00 & 2.03 & 2.03 \\
$\mathrm{Co}$ & 206.75 & 10 & 0.10 & 2067.50 & 206.75 & 20.68 \\
$\mathrm{~Pb}$ & 1693.25 & 5000 & 0.00 & 33.87 & 0.01 & 0.34 \\
$\mathrm{Mn}$ & 254.25 & 200 & 0.01 & 127.13 & 0.64 & 1.27 \\
$\mathrm{Zn}$ & 1294 & 2000 & 0.00 & 64.70 & 0.03 & 0.65 \\
$\mathrm{Fe}$ & 1380.25 & 5000 & 0.00 & 27.61 & 0.01 & 0.28 \\
\hline
\end{tabular}

Table 4. Pearson's correlation analysis of heavy metal concentrations at all seasons in STP effluent.

\begin{tabular}{|c|c|c|c|c|c|c|c|c|c|c|}
\hline \multicolumn{11}{|c|}{ Correlations } \\
\hline & & As & B & $\mathrm{Cd}$ & $\mathrm{Cr}$ & Co & $\mathrm{Pb}$ & $\mathrm{Mn}$ & $\mathrm{Zn}$ & $\mathrm{Fe}$ \\
\hline \multirow{3}{*}{ As } & Pearson Correlation & 1 & 00.938 & 0.794 & 0.928 & 0.793 & $0.998^{* *}$ & 0.868 & 0.840 & $10.000^{* *}$ \\
\hline & Sig. (2-tailed) & & 00.062 & 0.206 & 0.072 & 0.207 & 0.002 & 0.132 & 0.160 & 0.000 \\
\hline & $\mathrm{N}$ & 4 & 4 & 4 & 4 & 4 & 4 & 4 & 4 & 4 \\
\hline \multirow{3}{*}{$\mathrm{B}$} & Pearson Correlation & 0.938 & 1 & 0.539 & 0.746 & 0.549 & 0.929 & 0.645 & 0.601 & 0.937 \\
\hline & Sig. (2-tailed) & 0.062 & & 0.461 & 0.254 & 0.451 & 0.071 & 0.355 & 0.399 & 0.063 \\
\hline & $\mathrm{N}$ & 4 & 4 & 4 & 4 & 4 & 4 & 4 & 4 & 4 \\
\hline \multirow{3}{*}{$\mathrm{Cd}$} & Pearson Correlation & 0.794 & 00.539 & 1 & $0.963^{*}$ & 0.943 & 0.811 & $0.991^{* *}$ & $0.996^{* *}$ & 0.798 \\
\hline & Sig. (2-tailed) & 0.206 & 00.461 & & 0.037 & 0.057 & 0.189 & 0.009 & 0.004 & 0.202 \\
\hline & $\mathrm{N}$ & 4 & 4 & 4 & 4 & 4 & 4 & 4 & 4 & 4 \\
\hline \multirow{3}{*}{$\mathrm{Cr}$} & Pearson Correlation & 0.928 & 00.746 & $0.963^{*}$ & 1 & 0.922 & 0.939 & $0.990^{*}$ & $0.979^{\star}$ & 0.930 \\
\hline & Sig. (2-tailed) & 0.072 & 00.254 & 0.037 & & 0.078 & 0.061 & 0.010 & 0.021 & 0.070 \\
\hline & $\mathrm{N}$ & 4 & 4 & 4 & 4 & 4 & 4 & 4 & 4 & 4 \\
\hline \multirow{3}{*}{ Co } & Pearson Correlation & 0.793 & 00.549 & 0.943 & 0.922 & 1 & 0.787 & $0.951^{*}$ & $0.961^{*}$ & 0.790 \\
\hline & Sig. (2-tailed) & 0.207 & 00.451 & 0.057 & 0.078 & & 0.213 & 0.049 & 0.039 & 0.210 \\
\hline & $\mathrm{N}$ & 4 & 4 & 4 & 4 & 4 & 4 & 4 & 4 & 4 \\
\hline \multirow{3}{*}{$\mathrm{Pb}$} & Pearson Correlation & $0.998^{* *}$ & 0.929 & 0.811 & 0.939 & 0.787 & 1 & 0.880 & 0.851 & $0.999^{* *}$ \\
\hline & Sig. (2-tailed) & 0.002 & 0.071 & 0.189 & 0.061 & 0.213 & & 0.120 & 0.149 & 0.001 \\
\hline & $\mathrm{N}$ & 4 & 4 & 4 & 4 & 4 & 4 & 4 & 4 & 4 \\
\hline \multirow{3}{*}{ Mn } & Pearson Correlation & 0.868 & 0.645 & $0.991^{\star *}$ & $0.990^{*}$ & $0.951^{\star}$ & 0.880 & 1 & $0.998^{* *}$ & 0.870 \\
\hline & Sig. (2-tailed) & 0.132 & 0.355 & 0.009 & 0.010 & 0.049 & 0.120 & & 0.002 & 0.130 \\
\hline & $\mathrm{N}$ & 4 & 4 & 4 & 4 & 4 & 4 & 4 & 4 & 4 \\
\hline \multirow{3}{*}{$\mathrm{Zn}$} & Pearson Correlation & 0.840 & 0.601 & $0.996^{* *}$ & $0.979^{*}$ & $0.961^{\star}$ & 0.851 & $0.998^{* *}$ & 1 & 0.842 \\
\hline & Sig. (2-tailed) & 0.160 & 0.399 & 0.004 & 0.021 & 0.039 & 0.149 & 0.002 & & 0.158 \\
\hline & $\mathrm{N}$ & 4 & 4 & 4 & 4 & 4 & 4 & 4 & 4 & 4 \\
\hline \multirow{3}{*}{$\mathrm{Fe}$} & Pearson Correlation & $1.000^{* *}$ & 0.937 & 0.798 & 0.930 & 0.790 & $0.999 * *$ & 0.870 & 0.842 & 1 \\
\hline & Sig. (2-tailed) & 0.000 & 0.063 & 0.202 & 0.070 & 0.210 & 0.001 & 0.130 & 0.158 & \\
\hline & $\mathrm{N}$ & 4 & 4 & 4 & 4 & 4 & 4 & 4 & 4 & 4 \\
\hline
\end{tabular}

${ }^{*}$. Correlation is significant at the 0.01 level (2-tailed). ${ }^{*}$. Correlation is significant at the 0.05 level (2-tailed). 
metals or similar sources of input [30] [31]. The strong correlation between two heavy metals indicates a strong dependence of both metals on the same causal factor [30] [32].

\section{Conclusions}

Our study on STP effluent for Agra stretch revealed that Jaganpur site highly polluted with heavy metals, alkalinity, hardness and other toxic ions. The results showed that the physicochemical parameters assessed to determine the SAR (13 - 20) and RSC (-10 to 11) for STP effluent confirm to moderate to severe range of restrictive use for irrigation to crops fields. As such, a safer side practice, i.e., desired dilution and judicious use of polluted/contaminated STP effluent should follow in long-term use of water for irrigation of crops in the studied stretch for avoiding the adverse influences on human, animal and soil health as well as on environmental quality.

HPI (1692.4) of STP effluent shows critically polluted with heavy metals and unsafe for irrigation in all seasons throughout the year. MQI (58.1) is much higher than the critical limit at all sites indicating severe total metal pollution. Pearson's correlation analysis showed that all heavy metals had a common source of pollution. The study will be useful in designing policies and action plans to concerned wastewater treatment management for pollution abatement and restoration of the used clean water. Sewage treatment plants efficiency to try and mitigate the inputs thereof and therefore develop the proper, effective eco-friendly methods to remediate the amount of toxicity entering the human bodies through the food chain.

\section{Acknowledgements}

We would like to extend our sincere thanks to the Institute "Dayalbagh Educational Institute Dayalbagh Agra" for providing us research labs and a great environment to work. Thanks are also given to the reviewers and editors whose comments on the manuscript are greatly appreciated.

\section{Conflicts of Interest}

The authors declare no conflicts of interest regarding the publication of this paper.

\section{References}

[1] Singh, K.P., Mohan, D., Sinha, S. and Dalwani, R. (2004) Impact Assessment of Treated/Untreated Wastewater Toxicants Discharged by Sewage Treatment Plants on Health, Agricultural, and Environmental Quality in the Wastewater Disposal Area. Chemosphere, 55, 227-255.

https://doi.org/10.1016/j.chemosphere.2003.10.050

[2] Williams, M., Kookana, R.S., Mehta, A., Yadav, S.K., Tailor, B.L. and Maheshwari, B. (2019) Emerging Contaminants in a River Receiving Untreated Wastewater from an Indian Urban Centre. Science of the Total Environment, 647, 1256-1265. https://doi.org/10.1016/j.scitotenv.2018.08.084 
[3] Darré, E., Cadenazzi, M., Mazzilli, S.R., Rosas, J.F. and Picasso, V.D. (2019) Environmental Impacts on Water Resources from Summer Crops in Rainfed and Irrigated Systems. Journal of Environmental Management, 232,514-522. https://doi.org/10.1016/j.jenvman.2018.11.090

[4] Castorina, A., Consoli, S., Barbagallo, S., Branca, F., Farag, A., Licciardello, F. and Cirelli, G.L. (2016) Assessing Environmental Impacts of Constructed Wetland Effluents for Vegetable Crop Irrigation. International Journal of Phytoremediation, 18, 626-633. https://doi.org/10.1080/15226514.2015.1086298

[5] Pan, M., Wong, C.K.C. and Chu, L.M. (2014) Distribution of Antibiotics in Wastewater-Irrigated Soils and Their Accumulation in Vegetable Crops in the Pearl River Delta, Southern China. Journal of Agricultural and Food Chemistry, 62, 11062-11069. https://doi.org/10.1021/jf503850v

[6] Misaghi, F., Delgosha, F., Razzaghmanesh, M. and Myers, B. (2017) Introducing a Water Quality Index for Assessing Water for Irrigation Purposes: A Case Study of the Ghezel Ozan River. Science of the Total Environment, 589, 107-116. https://doi.org/10.1016/j.scitotenv.2017.02.226

[7] Bhuiyan, M.A.H., Islam, M.A., Dampare, S.B., Parvez, L. and Suzuki, S. (2010) Evaluation of Hazardous Metal Pollution in Irrigation and Drinking Water Systems in the Vicinity of a Coal Mine Area of Northwestern Bangladesh. Journal of Hazardous Materials, 179, 1065-1077. https://doi.org/10.1016/j.jhazmat.2010.03.114

[8] Hurley, T., Sadiq, R. and Mazumder, A. (2012) Adaptation and Evaluation of the Canadian Council of Ministers of the Environment Water Quality Index (CCME WQI) for Use as an Effective Tool to Characterize Drinking Source Water Quality. Water Research, 46, 3544-3552. https://doi.org/10.1016/j.watres.2012.03.061

[9] Murthy, C.S., Yadav, M., Mohammed Ahamed, J., Laxman, B., Prawasi, R., Sesha Sai, M.V.R. and Hooda, R.S. (2015) A Study on Agricultural Drought Vulnerability at Disaggregated Level in a Highly Irrigated and Intensely Cropped State of India. Environmental Monitoring and Assessment, 187, 140. https://doi.org/10.1007/s10661-015-4296-x

[10] Tran, Q.K., Schwabe, K.A. and Jassby, D. (2016) Wastewater Reuse for Agriculture: Development of a Regional Water Reuse Decision-Support Model (RWRM) for Cost-Effective Irrigation Sources. Environmental Science \& Technology, 50, 9390-9399. https://doi.org/10.1021/acs.est.6b02073

[11] Kükrer, S. and Mutlu, E. (2019) Assessment of Surface Water Quality Using Water Quality Index and Multivariate Statistical Analyses in Saraydüzü Dam Lake, Turkey. Environmental Monitoring and Assessment, 191, 71. https://doi.org/10.1007/s10661-019-7197-6

[12] Udhayakumar, R., Manivannan, P., Raghu, K. and Vaideki, S. (2016) Assessment of Physico-Chemical Characteristics of Water in Tamilnadu. Ecotoxicology and Environmental Safety, 134, 474-477. https://doi.org/10.1016/j.ecoenv.2016.07.014

[13] Tiwari, A.K., De Maio, M., Singh, P.K. and Mahato, M.K. (2015) Evaluation of Surface Water Quality by Using GIS and a Heavy Metal Pollution Index (HPI) Model in a Coal Mining Area, India. Bulletin of Environmental Contamination and Toxicology, 95,304-310. https://doi.org/10.1007/s00128-015-1558-9

[14] Bouaroudj, S., Menad, A., Bounamous, A., Ali-Khodja, H., Gherib, A., Weigel, D.E. and Chenchouni, H. (2019) Assessment of Water Quality at the Largest Dam in Algeria (Beni Haroun Dam) and Effects of Irrigation on Soil Characteristics of Agricultural Lands. Chemosphere, 219, 76-88.

https://doi.org/10.1016/j.chemosphere.2018.11.193 
[15] De La Mora-Orozco, C., Flores-Lopez, H., Rubio-Arias, H., Chavez-Duran, A. and Ochoa-Rivero, J. (2017) Developing a Water Quality Index (WQI) for an Irrigation Dam. International Journal of Environmental Research and Public Health, 14, pii: E439. https://doi.org/10.3390/ijerph14050439

[16] Li, Y.L., Qiao, J.F., Dong, T.Y. and Wang, H.J. (2016) Hyperspectral Inversion of Soil Water and Salt Content in Soils with Different Textures. The Journal of Applied Ecology, 27, 3807-3815.

[17] Lin, C.E., Chen, C.T., Kao, C.M., Hong, A. and Wu, C.Y. (2011) Development of the Sediment and Water Quality Management Strategies for the Salt-Water River, Taiwan. Marine Pollution Bulletin, 63, 528-534. https://doi.org/10.1016/j.marpolbul.2011.02.005

[18] Sadovski, A.Y., Fattal, B., Goldberg, D., Katzenelson, E. and Shuval, H.I. (1978) High Levels of Microbial Contamination of Vegetables Irrigated with Wastewater by the Drip Method. Applied and Environmental Microbiology, 36, 824-830.

[19] Zhang, H., Khan, A., Tan, D.K.Y. and Luo, H. (2017) Rational Water and Nitrogen Management Improves Root Growth, Increases Yield and Maintains Water Use Efficiency of Cotton under Mulch Drip Irrigation. Frontiers in Plant Science, 8, 912. https://doi.org/10.3389/fpls.2017.00912

[20] Subbaraman, R., Shitole, S., Shitole, T., Sawant, K., O’Brien, J., Bloom, D.E. and Patil-Deshmukh, A. (2013) The Social Ecology of Water in a Mumbai Slum: Failures in Water Quality, Quantity, and Reliability. BMC Public Health, 13, 173. https://doi.org/10.1186/1471-2458-13-173

[21] Jasmin, I. and Mallikarjuna, P. (2014) Physicochemical Quality Evaluation of Groundwater and Development of Drinking Water Quality Index for Araniar River Basin, Tamil Nadu, India. Environmental Monitoring and Assessment, 186, 935-948. https://doi.org/10.1007/s10661-013-3425-7

[22] Troldborg, M., Duckett, D., Allan, R., Hastings, E. and Hough, R.L. (2017) A Risk-Based Approach for Developing Standards for Irrigation with Reclaimed Water. Water Research, 126, 372-384. https://doi.org/10.1016/j.watres.2017.09.041

[23] Sanchez-Ramos, D., Sánchez-Emeterio, G. and Florín Beltrán, M. (2016) Changes in Water Quality of Treated Sewage Effluents by Their Receiving Environments in Tablas de Daimiel National Park, Spain. Environmental Science and Pollution Research, 23, 6082-6090. https://doi.org/10.1007/s11356-015-4660-y

[24] Zhang, D., Tao, Y., Liu, X., Zhou, K., Yuan, Z., Wu, Q. and Zhang, X. (2016) Spatial and Temporal Variations of Water Quality in an Artificial Urban River Receiving WWTP Effluent in South China. Water Science \& Technology, 73, 1243-1252. https://doi.org/10.2166/wst.2015.592

[25] Varekar, V., Karmakar, S., Jha, R. and Ghosh, N.C. (2015) Design of Sampling Locations for River Water Quality Monitoring Considering Seasonal Variation of Point and Diffuse Pollution Loads. Environmental Monitoring and Assessment, 187, 376. https://doi.org/10.1007/s10661-015-4583-6

[26] Camacho-Cristóbal, J.J., Rexach, J. and González-Fontes, A. (2008) Boron in Plants: Deficiency and Toxicity. Journal of Integrative Plant Biology, 50, 1247-1255. https://doi.org/10.1111/j.1744-7909.2008.00742.x

[27] Li, X., Han, G., Liu, M., Yang, K. and Liu, J. (2019) Hydro-Geochemistry of the River Water in the Jiulongjiang River Basin, Southeast China: Implications of Anthropogenic Inputs and Chemical Weathering. International Journal of Environmental Research and Public Health, 16, 440. https://doi.org/10.3390/ijerph16030440

[28] Nishy, P. and Saroja, R. (2018) A Scientometric Examination of the Water Quality 
Research in India. Environmental Monitoring and Assessment, 190, 225. https://doi.org/10.1007/s10661-018-6601-y

[29] Verhoeven, J.T.A., Arheimer, B., Yin, C. and Hefting, M.M. (2006) Regional and Global Concerns over Wetlands and Water Quality. Trends in Ecology \& Evolution, 21, 96-103. https://doi.org/10.1016/j.tree.2005.11.015

[30] Bhardwaj, R., Gupta, A. and Garg, J.K. (2018) Impact of Heavy Metals on Inhibitory Concentration of Escherichia coli-A Case Study of River Yamuna System, Delhi, India. Environmental Monitoring and Assessment, 190, 674. https://doi.org/10.1007/s10661-018-7061-0

[31] Krishna, A.K. and Mohan, K.R. (2014) Risk Assessment of Heavy Metals and Their Source Distribution in Waters of a Contaminated Industrial Site. Environmental Science and Pollution Research, 21, 3653-3669.

https://doi.org/10.1007/s11356-013-2359-5

[32] Polat, F., Akın, Ş., Yıldırım, A. and Dal, T. (2016) The Effects of Point Pollutants-Originated Heavy Metals (Lead, Copper, Iron, and Cadmium) on Fish Living in Yeşilırmak River, Turkey. Toxicology and Industrial Health, 32, 1438-1449. https://doi.org/10.1177/0748233714565709 